\title{
Holistic Management Design for Adult
}

\author{
Aloysius Hardoko ${ }^{1}$ \\ ${ }^{1}$ University of Mulawarman, Indonesia \\ Correspondence: Aloysius Hardoko. E-mail: ritapingky550@gmail.com
}

Received: March 15, 2018

Accepted: March 26, 2018 Online Published: June 22, 2018

doi:10.5539/ass.v14n7p32

URL: https://doi.org/10.5539/ass.v14n7p32

\begin{abstract}
This study aims at collecting data on adults' knowledge and behaviour on environmental degradation, government's programs in resolving environmental degradation, and alternative solution to resolve the environmental degradation through holistic management design for adults. Qualitative research using interview guidelines as a reference for the interview was implemented in order to collect data on the adults' knowledge; sample cases of environmental degradation completed with photos and interview guidelines were used to collect gather adults' behaviour (response) toward environmental degradation; interview guidelines were used as a reference for FGD to collect data on government programs which were implemented to resolve environmental degradaion after coal mining The alternative solution to resolve environmental degradation was the outcome of research and development conducted by Hardoko et al. in 2016 in different districts; however, these disricts shared similar problem characteristics since they are located in the same province of East Kalimantan.The location of this research is Berau District, East Kalimantan Province. The research respondents were 10 adults who were above 40 years old and lived around the coal mining site. The respondents of government programs were 4 staff from Mining and Energy Agency and Environment Agency. It applied the descriptive analysis and categorisation in tables which was interpreted. The adults' average knowledge on environmental degradation was in the category of good; while their behaviour on it was in the category of sufficient. The government programs which were implemented to resolve environmental degradation were in form of material assistance; however, there was not any non formal program to alter adults' behaviour from destructive behaviour to protective behaviour.This study found that the government programs were not suitable to resolve the environmental degradation in which behaviour was the root cause for the problems.. Having found this, a solution was offered in form of the knowledge and behaviour management design based on holistic approach for adult learning program as an alternative solution for government in solving environment problems after coal mining activities. The design is holistic because it includes knowledge, attitude, and behaviour aspect with contextual environment media which is covered in three stages of learning activities. This research has never been conducted before; particularly on the topic of adults knowledge and behaviour after mining in Berau District, East Kalimantan Province. The three stages of learning in the holistic management design for adults in solving the environmental degradation were the outcomes of the developed research conducted by Hardoko et al. 2016.
\end{abstract}

Keywords: holistic management, design, adult learning

\section{Introduction}

The results from several researches related to the Master plan for Acceleration and Expansion of Indonesia's Economic Development (Hardoko, 2013; Rahmawati \& Makrina, 2013) show that adult behaviour is one of major causes of environmental degradation in East Kalimantan. This is further compounded with government policieson coal miningwhich also threaten environment caused by the lack of environmental awareness. For an example: in East Kalimantan a massive deforestation has occurred since 1970s. It then grew and became rampant during 1990 - 2012. This deforestation is a clear result of wood industry, plantation area expansion, and big scale mining industry. The environmental degradation in East Kalimantan will continue with government policies on coal mining activities which allow 5,2 million hectares out of 12,7 million hectares in East Kalimantan area to be used for coal mining. This is stated in local government policy No.1/2016 on spatial planning 2016 - 2030.

It turned out that this behaviour and policies did not just stop there and it got a lot worse. There was also a large scale coal mining dredging activity as a result of the ease to obtain legal permit from the local and central government as East Kalimantan became the focus for third corridor of Master plan for Acceleration and Expansion of Indonesia's Economic Development where coal mining is one of conducted activities. Until now, 
these environmentally destructive activities keep going and continue to government's program namely one million hectares of palm oil plantations in which people participate in either through plasma program or self-management. Ironically, Indonesian especially who live in East Kalimantan have experienced the impacts from these environmentally destructive activities themselves. Drought during the dry season, forest fire, smog, floods during the rainy season, the increasing heat and unpredictable weather are some examples of the negative effects. These people could even answer and realised that human behaviour played a significant role in this destruction.

Several attemps initiated by related institutions namely Mining and Energy Agency and Environment Agency have not been effective to solve the problems since these attemps fails to address the fundamental issue which is changing the human behaviour among the adultsover 40 years old. Of the reason why the programs from Mining and Energy Agency of East Kalimantan Province and Berau District, and also BLH of Berau could not effectively solve the destruction is because they were not adjusted to the adult knowledge attitude and behaviour there which actually became the target of the programs in handling the destruction after mining. These programs which were initiated by the two agencies were mostly in forms of aids in stock raising, agriculture and scholarship. Educational programs like environment protection learnings for adults, which are focusing on environment protection behaviour are yet to be implemented.

Adult knowledge attitude and behaviour management is different from children knowledge and behaviour management, Knowles, M (1984). Since adults are not as fast as children in grasping new knowledge and since there is a difference in motivating adults in learning, particular strategies are needed to suit them, Knowles,M (1984). The program implementation to overcome environmental destruction through non-formal education can be conducted through adult counseling activities not just adjusted to the knowledge, behaviour and natural resources damages, but covering the cultivation of awareness or values which is linked to programs that solve environmental destruction holistically. Therefore, people's awareness and behaviour in protecting environment will become characters of them. When people have reached the character level where they own the environmental awareness and behavior, then later the programs to solve environmental problems can be conducted continuously.According to Rogers (1974), before adopting new behaviour, people go through the stages of awereness, interest, evaluation, trial, and adoption respectively.

Based on the description above, it is important to develop knowledge and behaviour management design based on a holistic approach which means comprehensive since it includes knowledge, behaviour and awareness aspect focusing on environment destruction after mining in adult learning activities. The problem faced is that aech aspect of knowledge, attitudes, and behavior runs independently in adult learning so that there is no integration between these there aspect as a whole resulting environmental destructive behavior still occurs in adult through holistic management design it will be applied thoroughly in adult learning incorporating knowledge, attitude, and behavior elements adapted to environmental damage around adult residence.

Adults are role models to children as they are the next generation to protect the environment. This holistic approach can shape the role modeling. Adults' daily life examples are very important, especially from those who are considered as public figures. Related to the changing behaviour education, these public figures will encourage the behaviour changes process since they are well respected and they are the rolde models for the local people . People have a tendency to follow what public figures say and do. Therefore, examples from them are factors which can influence people's habit in protecting the environment and break bad habits which are considered as part of the culture. Adults handle it more effectively since they are considered more capable to think and they are expected to be able to change behaviour in habits since childhood.

Behaviour is defined as organisms' actions and reactions towards its environment. New behaviour occurs when there is something needed to cause reaction, called stimulus. Thus, certain stimulus will bring certain reaction or behaviour (Notoatmodjo, 1985). Behaviour is an organism's obseravle and learable action (Winter, 2000).

These viewpoints require the conducted programs to be a problem solving model to environmental destruction as a result of mining activities and it must related with the adults' experiencenamely knowledge and behavior, Knowles,1984, Knowles, 1984. The adults referred in this research are people above 40 years old who live around the mine and experience the immediate impacts of the mining activities. The characeristics which need to be understood are their knowledge, behaviour, skills and the supporting resources in doing their daily activities in society. It is very important to understand their characterics before the programs implementation. These characteristics are used to be the stimulus to change behaviour. By doing so, it will be easier to observe and learn the adults' behaviour changes after the implementation of the programs.

After considering the incompability between the environmental destruction and the implemented programs, 
which were conducteduntil 2015, by Energy Agency in the Province and District level of Berau, and the Environment Agency in District of Berau, the purposes of this research are described as follow:

1. To obtain in-depth data on the adults' knowledge and behaviour which explains their environmentally destructive behaviour after coal mining activities stop operating.

2. To obtain an overview on government's attempts in resolving environmental destruction after coal mining activities stop operating, which were conducted by Energy Agency in East Kalimantan Province and Berau District, and Environment Agency in Berau District.

3. To develop knowledge and behaviour management design with holistic-based approach to be implemented effectively in adult learning, which is focusing on changing their behaviour from destructing to protecting the environment after coal mining activities stop operating.

4. Offering alternative solution to the environmental degradation.

\section{Method}

To reach the aim, this study applied qualitative research method (Berg, 2001; Cohen et al., 2007) using:

1. Interview guideline which was used as a reference to the interview in order to collect data on adults' knowledge focusing on the types and the causes of environmental degradation.

2. Files consisting cases and photos of environmental degradation followed by interviews to receive adults' reaction (behaviour) on environmental degradation cases.

3. Interview guidelines as a reference in FGD (C.M \& Frick, 1999; Richey \& Nelson, 1996), (Morgan, 1988; Powell \& Singgle, 1996) with Department of Energy and Mineral Resources and BLH to collect data on the government program which concerned with solving environmental degradation after coal mining.

4. The alternative solution to the environmental degradation was the outcome of research and development (R\&D) conducted by Hardoko et al. (2016) in different locations ; however, it shared the same problem characteristics since all locations were still in the same province. The location of the research was in Berau District, East Kalimantan Province. The respondents of this research were 4 participants from BLH and 4 participants from Department of Energy and Mineral Resources. The data then were analysed using descriptive analysis followed by categorising into tables and interpreting.

\section{Research Procedure}

\subsection{Preparation Stage}

1. Developing 3 types of interview guidelines as a reference for conducting interview with 10 adult respondents and 8 respondents from government institutions namely Department of Energy and Mineral Resourcesand BLH. The three types of interview guidelines were: 1. Interview guidelines to gather required data on adults' knowledge of the types and the causes of environmental degradation. 2. Interview guidelines to gather required data on adults' responses after knowing and seeing the photos of environmental degradation around their area. 3. Interview guidelines to gather required data on government programs which aimed at solving environmental degradation after coal mining.

2. Preparing a sample case of environmental degradation after coal mining activities and the photos of it.

3. Preparing the knowledge and behaviour management design based on holistic approach for adult learning program as an alternative solution for government in solving environment problems after coal mining activities. This design was the outcome of a research and development conducted by Hardoko et al. in 2016. The knowledge and behaviour management design based on holistic approach for adult learning program aimed at facilitating adults' behaviour changes from the destructive behaviour to the protective one.This destructive behaviour was the root cause of environment problems in East Kalimantan Province.

\subsection{Implementation Stage}

The researchers conducted interviews using the prepared interview guidelines, ran an interview analysis, and presented the analysis results in the category of inadequate, sufficient, good, and excellent for the knowledge aspect. Related to the behaviour aspect, an environment degradation sample case was presented which was also supported by the photos. Then, interviews were conducted to see and obtain respondets' responses. The next step was analysing the responses and presented them in a table into the category of inadequate, sufficient, good, excellent (in protecting environment). The data on government programs were gathered through questions in FGD using the interview guidelines which were focusing on types of programs. 


\subsection{Follow Up and the Research Outcome Implication}

The follow up stage was implemented in FGD activity by offering Department of Energy and Mineral Resources and BLH an alternative solution, using a knowledge and behaviour management design based on holistic approach for adult learning program to overcome environment degradation after coal mining activities. This design aimed at facilitating adults' behaviour changes from the destructive behaviour to the protective behaviour. This destructive behaviour was the root cause of environment problems in East Kalimantan Province.The knowledge and behaviour management design based on holistic approach for adult learning programwas the outcome of a research and development conducted by Hardoko et al. in 2016. The implication of this research is the alternative solution to help government in resolving environmental degradation especially in the attempts in changing people's behaviour from the destructive behaviour to the protective behaviour through adult learning program which is focusing on the protection of environment.

\section{Results}

Table 1. Research results related to adults' knowledge

\begin{tabular}{ccccc}
\hline \multirow{2}{*}{ Question Topic } & \multicolumn{3}{c}{ Knowledge Category } \\
\cline { 2 - 5 } & inadequate & enough & good & excellent \\
\hline The types of environmental degradation & & 6 & 4 \\
The causes of environmental degradation & 5 & 2 & 8 \\
The solutions for environmental degradation & 5 & 5 & & \\
\hline
\end{tabular}

Table 1 shows the categorisation result of adults' knowledge from 10 respondents. The focus of the interview questions was on the types and the causes of the environmental degradation. The result shows that the average knowledge was in the category of good.

Table 2. Research results related to adults' behaviour

\begin{tabular}{ccccc}
\hline \multirow{2}{*}{ Question Topic } & \multicolumn{3}{c}{ Knowledge Category } \\
\cline { 2 - 4 } & inadequate & enough & good & excellent \\
\hline The behaviour towards environmental degradation & & 4 & 6 & \\
The behaviour towards the causes of environmental degradation & 2 & 7 & 1 \\
The behaviour towards solutions for environmental degradation & 4 & 6 & & \\
\hline
\end{tabular}

Table 2 shows the categorisation of adults' behaviour (response) related to the environmental degradation from 10 respondents. Having heard the environmental degradation cases which were supported by photos of the environmental degradation, the respondents answered interview questions. The result shows that the average behaviour was in the category of sufficient.

Table 3. Government's programs to solve environmental degradation problems.

\begin{tabular}{ll}
\hline Institution & Program \\
\hline Energy & Agricultural seeds, plantation seeds, livestock, fishery, scholarships in cooperation with the \\
Agency & company \\
Environment & Agricultural seeds, plantation seeds, livestock, fishery, scholarships in cooperation with the \\
Agency & company \\
\hline
\end{tabular}

Table 3 shows government programs which have been implemented so far in resolving the environmental degradation from the 4 respondents. The result shows that the solutions were in form of material assistance.

\section{Discussion}

The research result from Table 1 shows that adults' knowledge on the types of environmental degradation, the causes of environmental degradation, and the solutions for environmental degradation are in the category of "good". It means that the adults have good knowledge of environmental degradation. The research results from Table 2 show that adults" knowledge of the behaviour towards environmental degradation, the behaviour towards 
the causes of environmental degradation, and the behaviour towards solutions for environmental degradation is "enough". It indicates that their knowledge is not aligned with their behaviour towards environmental degradation.

However, this result is aligned with the results from other studies (BPS,2012) conducted by The Ministry of Environment and Forestry, which share the same purpose in viewing pro-environmental knowledge, attitudes, and behaviour in 33 provinces nationally. The results indicate that the average of pro-environmental behaviour is under $0,57 \%$ and is not aligned with people's high knowledge of environment at $60,2 \%$ (BPS,2012). It shows that the index of low pro-environmental behaviour is not synchronised with the sufficient knowledge they own to understand the real environmental problems and the reality of the weak intention towards pro-environmental behaviour.

The results from Tables 1 and 2 also indicate that the adults have got good knowledge and adequate tendency of behaviour towards the environment. These results are used as the basis for the make use of knowledge and behaviour management design with holistic-based approach in adult learning on environmental degradation after the coal mining stop operating.

The basic consideration for this reference is Notoatmodjo's opinion (2007) which states adults have got knowledge to change their attitude and behaviour since the behaviour change is influenced by factors in form of knowledge, attitude, beliefs, values and predisposed motivation. This view suggests that the implemented programs to solve the environmental problems resulted from coal mining activities should be connected to adults' knowledge and behaviour.

The research results from Table 3 related to Government's programs to solve environmental degradation problems show that all programs are in form of aid and there are no programs which focus on changing adults' behaviour through counseling, education, and learning which focus on changing adults' behaviour as an attempt to solve environmental degradation problems. The result of this research shows that goverment programs to overcome environmental degradation as a result of coal mining activities have not solved the root cause which is human behaviour changes, therefore this environmental degradation problems continue to occur. The adult behaviour changes effectively occur in non-formal education through learnings with knowledge and behaviour management. According to Bloom in Kratwoll and Anderson (2001), changing human behaviour involves knowledge and bahaviour.

Human behaviour is a balanced condition between the driving forces and the restraining forces. Based on the incompatibility between the adults' behaviour as the root cause of environmental degradation and the government's implemented programs, this research attempts to offer alternative solutions through knowledge and behaviour management design with holistic-based approach in adult learning after coal mining activities stop operating. The holistic approach is intended to include knowledge, attitude, awareness, and environmental degradation forms thoroughly in the learning as stimulus or driving forces to reduce the restraining forces; starting from the initial learning activities, main learning activities to post-learning activities.

Table 1 and 2 show that adults' average knowledge and behaviour were in the category of good and sufficient; however, the result did not align with their attitude which reflected destructive behaviour toward environment. The research and development conducted by Hardoko et al. in 2016 found out that holistic approach is needed to change the attitude which are not corresponding to the knowledge and the behaviour. In other words, knowledge, attitude, and behaviour aspect need to be synchronised through environmentally contextual learning media. These aspects were in sync through 3 stages of learning: initial learning activities, main learning activities, and post-learning activities.

The way this holistic approach was implemented in the initial learning activities was through questions raised by the facilitator to the learning participants; What damages can you see and what are the consequences? Then, it continued to the next question; How are you supposed to react to the damages? In the next step, the facilitator motivated the participants by stating that they can be a role model in dealing with the environmental degradation, since they have got good knowledge and behaviour towards it. Therefore, that day's activity was that the facilitator delivered the learning activity topic on the resolving environmental problems related to floods.

The implementation of holistic approach in the main learning activities started when the facilitator formed groups. After the group formation, the facilitator distributed a counseling and learning activity sheet (LKPP). After that, the facilitator explained how to do the LKPP. Next, the facilitator assigned the groups to do the LKPP, while assisting as the facilitator, and later asked the representative of each group to present their work. The LKPP contains the purpose of resolving environmental degradation caused by flood, cases of environmental degradation caused by flood, the causes of flood, and questions on how to prevent environmental degradation in 
order to stop flood.

For an example: The River Kelai (around the location) always overflows in the rainy season. Thus, the residential areas, schools, plantations, and other places are always flooded. The impacts of this are: parents cannot go to work, children cannot go to school, and people lose their jobs as the plantations are flooded. Question number 1: what makes The River Kelai overflow? Question number 2: What problems have you got when The River Kelai overflows? Question number 3: What concrete steps can you take to prevent The River Kelai from overflowing therefore you will not face the same problem oever and over again?

The implementation of a holistic approach in the post-learning activities was conducted after the group presentation. The facilitator gave rewards to groups with good work result. The facilitator motivated groups which could not show the good work result to perform better during the following learing sessions. In the next step, the facilitator assigned the groups to choose and implement a concrete work they could do in their environment to prevent The River Kelai from overflowing.

The real challenge to environmental sustainibility is the challenge from people's behaviour changes (Oskamp, 2000; Howard, 2000; McKenzie-Mohr, 2000; Stern, 2000; Winter, 2000; Rosario \& Jamias, 2010). According to the concept from these six articles, it is important to seek soulutions to environmental degradation problems with the focus on the change of behaviour from destructing to protecting the environment.The developed knowledge and behaviour management design which based on holistic approach is an attempt to solve the environmental degradation focusing on behaviour changes.

Hines Hungerford and Tomera (1986) in a meta-analysis concludes that the theory of planned behaviour is still relevant to explain pro-environmental behaviour with the classic behaviour proposition that behaviour intention is a relevant predictor related immediately to behaviour, whereas intention is formed of attitude, subjectives norms, and behavioural control perceptions. The theory of planned behaviour is an organized theory over a period of time, which has been proven in describing pro-environmental behaviour in several studies (Armitage \& Conner, 2001).

The implementation of holistic approach in every stage of learning is a form of implementation of the theory of planned behaviour.

The implementation of knowledge and behaviour management based on holistic approach is explained through this leaning design.The initial activities: motivation counselling, explaining the learning activities topic, explaining the purpose of learning activites linked to the environmental degradation around the participants (adults).

The main activity: learning. The learning facilitator grouped the participants and then distributed the activity sheets to them. Next, the facilitator gave instructions on how to complete the assignments from the activity sheet followed by group discussion on completing the assignments. Thereafter, each group presented the result of their discussion. The activity sheet contains information related to environmental degradation and the attempts to overcome the problems with the context of real environmental degradation happening around the participants.

The post activity: The facilitator assigned the participants to choose activities to be implemented to overcome environmental degradation as a concrete form of their attempts in overcoming environmental degradation that they start from their neighbourhood.

\section{Acknowledgement}

I thank The Directorate General of Research and Technology Research and Development, The Directorate of Research and Community Service of Research, Technology and Higher Education which have facilitated the research funding for 3 consecutive years. This year is the third year, funding the last year through ongoing grant fund contract research graduate research in 2017.

\section{References}

Anderson, L. W., \& Krathwohl, D. R. et al (Eds.) (2001). A Taxonomy for Learning, Teaching, and Assessing: A Revision of Bloom's Taxonomy of Educational Objectives. Allyn \& Bacon. Boston, MA (Pearson Education Group).

Armitage, C. J., \& Conner, M. (2001). Efficacy of a minimal intervention to reduce fat intake. Social Science and Medicine, 52, 1517-1524.

Cohen, L., \& Manion, L. (1994). Research Methods in Education (4th ed.). London: Routledge.

Hardoko. (2013). Resolusi Konflik terkait aktivitas Tambang Batubara Kegiatan Ekonomi Koridor 3MP3EI 
Kalimantan Timur.Laporan hasil penelitian MP3EI tahun 2013.

Hines, J. M., Hungerford, H. R., \& Tomera, A. N. (1986/87). Analysis and synthesis of research aresponsible environmental behavior: a meta-analysis. Journal of Environmental Education, 18(2), 1-8.

Howard, G. S. (2000). Adapting human lifestyles for the 21st century. American Psychologist, 55, 509-515.

Hurlock, E. (1999). Psikologi Perkembangan (Indonesian translation). Jakarta: Erlangga.

Konwles, M. (1984a). The adult Leaner: A Neglected Species (3rd ed.). Houston: Gulf Publishing.

Konwles, M. (1984b). Andragogy in Action. San Fransisco: Jossey-Bas.

Morgan. D. L. (1998). Focus Groups as Qualitative Research (Qualitative Research Methods).

McKenzie-Mohr, D. (2000). Promoting sustainable behavior: an introduction to community - basedsocial marketing. Journal of Social Issues, 56(3), 543-554.

Notoatmodjo, S., \& Sarwono, S. (1985). Pengantar Ilmu Perilaku Kesehatan (p. 23). Jakarta: Badan Penerbit Kesehatan Masyarakat Fakultas Kesehatan Masyarakat Universitas Indonesia.

Notoatmodjo, Soekidjo, \& Km, S. (2007). Promosi Kesehatan dan Ilmu Perilaku. Jakarta: Rineksa Cipta.

Oskamp, S. (2000). Environmentally responsible behavior: teaching and promoting it effectively. Analyses of Social Issues and Public Policy, 2(1), 173-182.

Rahmawati dan Makrina, (2013). Pemberdayaan Ekonomi Masyarakat sekitar Kegitan TambangTerkait Koridor 3 MP3EI Kalimantan Timur. Laporan hasil penelitian MP3EI tahun 2013.

Reigeluth, C. M., \& Frick, T. W. (1999). Formative research: A methodology for creating and improving design theories. In C. M. Reigeluth (Ed.), Instructional-Design Theories and Models - A New.

Rosario dan Jamias. (2010). Village-level Knowledge, Attitudes and Practices on Solid WasteManagement in Sta.Rosa City, Laguna, Philippines. Journal of Environmental Science and Management, 13(1), 35-51.

Rogers, B. J., \& Anstis, S. M. (1972). Intensit versus adaptatton and the Pulfrich Stereophenom: non. I isimRcs. 12. 909-9X Steinbach vI. J.

Sofyian. (2017). Analisis Deskriptif untuk penelitian. Rajawali Press. Indonesia

Stern, P. C. (2000). Toward a coherent theory of environmentally significant behavior. Journal of Social Issues, $56(3), 407-424$.

Winter, D. D. N. (2000). Some big ideas for some big problems. American Psychologist, 55, 516-522.

\section{Copyrights}

Copyright for this article is retained by the author(s), with first publication rights granted to the journal.

This is an open-access article distributed under the terms and conditions of the Creative Commons Attribution license (http://creativecommons.org/licenses/by/4.0/). 